Research article

\title{
FIELD TRIAL ON GLUCOSE-INDUCED INSULIN RESPONSE IN HIGH-YIELDING DAIRY COWS UNDER DIFFERENT ENVIRONMENTAL TEMPERATURES
}

\author{
VUJANAC Ivan ${ }^{1}$, PRODANOVIĆ Radiša ${ }^{1}$, KORIĆANAC Goran², BOJKOVSKI \\ Jovan ${ }^{1}$, SIMEUNOVIĆ Predrag ${ }^{1}$, PALAMAREVIĆ Milija ${ }^{1}$, NEDIĆ Sreten ${ }^{1}$, \\ CELESKA Irena ${ }^{3}$, KIROVSKI Danijela ${ }^{4 *}$
}

\begin{abstract}
${ }^{1}$ Department of Farm Animal Diseases, Faculty of Veterinary Medicine University of Belgrade, Belgrade, Serbia; ${ }^{2}$ Laboratory for Molecular Biology and Endocrinology, Vinča Institute of Nuclear Sciences University of Belgrade, Belgrade, Serbia; ${ }^{3}$ Department of Pathophysiology, Faculty of Veterinary Medicine, Ss. Cyril and Methodius University in Skopje, Macedonia; ${ }^{4}$ Department of Physiology and Biochemistry, Faculty of Veterinary Medicine University of Belgrade, Belgrade, Serbia
\end{abstract}

(Received 20 September 2016, Accepted 06 March 2017)

\begin{abstract}
This study aimed to evaluate glucose-induced insulin response in cows exposed to different temperature-humidity index. Twenty early lactating Holstein-Friesian cows were divided into 2 equal groups based on season, as summer (SU) and spring (SP). $\mathrm{SP}$ cows were not exposed to heat stress, while SU cows were exposed to moderate or severe heat stress. Milk production was recorded daily. Starting from day 30 of lactation, intravenous glucose tolerance test (IVGTT) was carried out three times at 30-day intervals. Blood samples were taken before (basal) and after glucose infusion, and glucose and insulin were measured at each sample point. The homeostatic model assessment (HOMA) index was calculated. Milk yield from days 30 to 40 and 64 to 90 of lactation were higher in SP cows than in SU cows. Basal glucose did not differ on days 30 and 60 of lactation, while basal insulin and HOMA were lower in SU compared to SP cows. On day 90 of lactation, SU cows had higher basal glucose, whereas basal insulin and HOMA did not differ. IVGTT results revealed that glucose tolerance was affected by heat stress such that $\mathrm{SU}$ cows had higher glucose clearance. Insulin responses to IVGTT did not differ on days 30 and 60 of lactation. Heat stress had a marked effect on insulin secretion on day 90 of lactation, illustrated by higher increments, peak concentrations and area under the curve for insulin in SU cows. Overall, season differences in glucose tolerance depend not only on heat stress and milk production but also on the stage of lactation.
\end{abstract}

Key words: dairy cows, heat stress, intravenous glucose tolerance test, HOMA

\footnotetext{
*Corresponding author: e-mail: dani@vet.bg.ac.rs
} 


\section{INTRODUCTION}

High ambient temperatures are one of the main environmental factors that impose stress on cows [1]. During the summer months, the increased environmental temperatures and relative humidity adversely affect the health and production performance of dairy cows. Besides mortality of animals due to heat stroke, even higher economic losses result from metabolic disorders, decreased milk yield and compromised fertility in heat-stressed cows $[2,3]$. High yielding dairy cows are more affected by heat stress than low yielding ones [4], because the upper critical temperature shifts downward as milk production, feed intake, and heat production increases [1].

Decline in milk production observed under conditions of heat stress is partly a result of reduced feed consumption [5,6]. Nevertheless, it is believed that decreased dry matter intake explains only 35 to $50 \%$ of that decline, whereas the remainder of depressed milk yield is a consequence of changes in the hormonal regulation of metabolic processes [7-9]. Baumgard and Rhoads (2007) [10] consider that the organism of high yielding dairy cows adapts to heat stress by using glucose as a source of energy instead of metabolizing fatty acids, due to the fact that oxidation of glucose releases less heat energy. Such a metabolic adaptation is explained by a more sensitive insulin response of peripheral tissues [8]. The largest number of studies on the effects of heat stress on metabolic adaptations was done on dairy cows which were in lactation for over 100 days [7-9]. At this time the lactating cows have reached a state of energy balance and the homeorhetic mechanisms were no more active. It is still an open question if the realignment of metabolism in conditions of heat stress is any different during the early stages of lactation when cows usually are in a stage of negative energy balance. Recently, Tao et al. (2012) [11] emphasized the importance of studying the insulin response of heat-stressed cows in all phases of productive-reproductive cycle including the dry period, too.

Several methods have been suggested in ruminants for assessing glucose metabolism and insulin sensitivity [12]. The hyperinsulinaemic euglycaemic clamp (HEC) and intravenous glucose tolerance test (IVGTT) are commonly used. Schoenberg et al. 2012 [13] reported that measurement of changes in insulin resistance as assessed by IVGTT corresponded closely to the results from HEC method, which is the gold standard for the evaluation of tissue sensitivity to insulin. The IVGTT has several advantages given that it does not overload the animal with glucose, the infusion can be given easily within the time limits, the blood glucose level is high enough to give a maximal insulin response, and urinary loss of glucose is minimal. Furthermore, this test can indirectly estimate which energy precursor is primarily used as a source of energy at a given metabolic and/or energy status of the animal. Moreover, based on glucose transport a rough estimate of the energy status of cows can be made [14]. However, since the responses to IVGTT do involve coordinated responses related to insulin as well as direct glucose effectiveness, interpretation of IVGT'T test is complicated, especialy in lactating ruminants. 
The major objective of this study was to assess the effects of heat stress on the adaptability of lactating cows. Namely, to study how different temperature-humidity indexes relate to changes in milk yield and overall glucose metabolism up to 90 days in lactation. Because the majority of research on the effects of heat stress has focused on mid lactating cows, our second objective was to examine if metabolic adaptation to heat stress differs in early lactating cows that are additionally exposed to NEB.

\section{MATERIALS AND METHODS}

\section{Experimental animals}

The research was conducted during the summer and spring season. Ten cows were selected randomly for the summer (SU) and ten for the spring (SP) investigation period. Cows were equally allocated to both groups according BCS and previous milk yield. All cows were clinically healthy and average lactation number per SU cows was $3.2 \pm 0.25$ and per SP cows was $2.9 \pm 0.28$. The animals were monitored daily from day 30 up to day 90 of lactation. The animal-related component of the study was approved by the Ethical Committee of the Faculty of Veterinary Medicine, University of Belgrade in accordance with the National Regulation on Animal Welfare.

\section{Housing}

The cows were housed in a tie-stall system in a commercial farm, located at coordinates 44 49'14" North and $20^{\circ} 27^{\prime} 44^{\prime \prime}$ East, in a stable which during the summer had no side walls and roof thermal insulation. The stable, besides roof ventilation, was not equipped with additional cooling system (fans or water misters). During the spring period rolled hay blocks $(140 \times 110 \mathrm{~cm})$ were attached to the side openings of the stable creating a "wall" that protected the animals from cold and air drafts.

\section{Environmental conditions}

Temperature, relative humidity, as well as dry and wet thermometer temperature measurements were taken hourly. The values were recorded at the meteorological station of the Republic Hydrometeorological Service of Serbia located $2 \mathrm{~km}$ from the farm. Based upon the collected data, the hourly heat indices (THI - temperaturehumidity index) were calculated for the whole period of the study. The THI was calculated according to the formula:

$$
\mathrm{THI}=(\mathrm{Tdt}+\mathrm{Twt}) \times 0.72+40.6
$$

Tdt - dry thermometer temperature

Twt - wet thermometer temperature

Based upon the recorded values, the average all-day THI was calculated. 


\section{Diet}

During the spring and summer period cows were fed with same diets in the form of total mix ration (TMR). The studied cows were fed twice a day (5.45 am and 5.30 pm). Complete details of feed intake were described by Vujanac et al. 2012 [6]. The ingredients and nutritive value of the diet are shown in Table 1 and 2, respectively.

Table 1. Composition of the total mixed ration fed to the cows from day 30 to day 90 of lactation

\begin{tabular}{lc}
\hline Ingredient & Kg/cow/day \\
\hline Alfalfa hay & 3.43 \\
\hline Corn silage $44 \% \mathrm{DM}^{1}$ & 9.50 \\
\hline Corn silage $33.94 \% \mathrm{DM}$ & 9.00 \\
\hline Alfalfa hay silage $47.40 \% \mathrm{DM}$ & 5.00 \\
\hline Brewer's grain $21.00 \% \mathrm{DM}$ & 5.00 \\
\hline Corn grain & 2.50 \\
\hline Barley grain & 1.50 \\
\hline Soybean grits & 1.30 \\
\hline Soybean meal $44 \% \mathrm{~N}^{2}$ & 1.13 \\
\hline Wheat flour & 1.30 \\
\hline Sugar beet pulp & 1.82 \\
\hline DextroFat SC & 0.40 \\
\hline Optigen $\mathrm{II}^{4}, 41 \% \mathrm{~N}$ & 0.14 \\
\hline Dextrose monohydrate & 0.10 \\
\hline Dicalcium phosphate $18 \% \mathrm{P}^{5}$ & 0.27 \\
\hline Magnesium oxide & 0.05 \\
\hline Sodium bicarbonate & 0.15 \\
\hline Sodium chloride (iodized) & 0.07 \\
\hline Calcium carbonate & 0.03 \\
\hline Total & 42.69 \\
\hline
\end{tabular}

${ }^{1}$ DM: dry matter; ${ }^{2} \mathrm{CP}$ or N: crude protein or nitrogen; ${ }^{3}$ DextroFat; ${ }^{4}$ Optigen II; ${ }^{5} \mathrm{P}$ : posphorus 
Table 2. Chemical composition of the total mixed ration fed to the cows from day 30 to day 90 of lactation

\begin{tabular}{lc}
\hline Dry matter (DM) kg & 23.63 \\
\hline Net energy of lactation (NEL) MJ & 163.03 \\
\hline Crude protein (CP) \% & 16.05 \\
\hline Rumen undegradable protein (RUP) \% & 5.06 \\
\hline Crude fat \% & 4.78 \\
\hline Acid detergent fiber (ADF) \% & 22.08 \\
\hline Neutral detergent fiber (NDF) \% & 35.48 \\
\hline Ca \% & 0.90 \\
\hline P \% & 0.52 \\
\hline Na \% & 0.36 \\
\hline Cl \% & 0.29 \\
\hline Mg \% & 0.34 \\
\hline K \% & 1.18 \\
\hline S \% & 0.22 \\
\hline Mn ppm & 82.40 \\
\hline Cu ppm & 25.64 \\
\hline Zn ppm & 96.90 \\
\hline Co ppm & 0.54 \\
\hline J ppm & 1.64 \\
\hline Fe ppm & 220.53 \\
\hline Se ppm & 0.70 \\
\hline Vit A IU $/ \mathrm{kg}$ & $21,273.58$ \\
\hline Vit D IU $/ \mathrm{kg}$ & $3,445.30$ \\
\hline
\end{tabular}

\section{Experimental procedure}

The 10 cows included in the study during the summer season were subjected to intravenous glucose tolerance test (IVGTT) three times at 30 day intervals starting from day 30 of lactation. The same test model was applied for the spring season, when other ten cows were subjected to the IVGTT three times, at monthly intervals (starting from day 30 of lactation). For the IVGTT, $500 \mathrm{mg} / \mathrm{kg}$ of body weight of glucose (glucose $50 \% \mathrm{wt} /$ vol; Zorka Sabac, Serbia) were infused in the jugular vein through $18 \mathrm{G}$ polyethylene catheter. The duration of glucose infusion was $6.0 \pm 1.0$ minutes.

\section{Sampling and analysis}

Blood samples for glucose analysis were taken from the jugular vein on the side of the neck not used for glucose infusion, into $\mathrm{Na}$-fluoride-oxalate tubes, immediately before 
glucose administration (minute 0) as well as 15, 30, 60 and 120 minutes after the end of glucose infusion. Samples for insulin analysis were obtained from the jugular vein with a sterile needle into plain tubes and allowed to clot for approximately 15 minutes. After centrifugation at $1,000 \mathrm{~g}$ for 20 minutes the serum was separated and stored at $-20^{\circ} \mathrm{C}$ until analyzed.

Concentrations of glucose were measured in whole blood enzymatically using commercial test strips (Abbott Diabetes Care Ltd., Oxon, UK). Insulin was determined using a commercial RIA kit (INEP Zemun, Serbia), intended for human sera, but validated for bovine sera. Cross reactivity of anti-human insulin antibodies with bovine insulin was close to $100 \%$. Standards for the radioimmunoassay were made from bovine insulin. Intra- and interassay coefficients of variation (CV) for insulin concentrations were less or close to $10 \%$ and less than $5 \%$, respectively.

\section{Milk yield}

Milk production (or yield) was measured daily starting from the first IVGT'T until the last IVGTT in the spring and summer season, using automatic "Delaval" milking equipment. The daily yields during a twice a day milking regime were recored as the sum of the morning and afternoon milking.

\section{Statistics}

To determine the differences between cows exposed to different ambient temperatures, glucose tolerance and endogenous insulin response to a standard glucose load were analyzed in both groups. Glucose tolerance was measured by calculating the glucose peak concentration $\left(\operatorname{Peak}_{\mathrm{glu}}\right)$, fractional turnover rate $(\mathrm{k})$, the half-life $\left(\mathrm{T}_{1 / 2}\right)$, and the area under the curve $\left(\mathrm{AUC}_{\mathrm{glu}}\right)$. The $\mathrm{k}$-value is defined as the glucose turnover rate or glucose disappearance rate and illustrates the clearance of the infused glucose. According to Kaneko (1997) [14], $\mathrm{k}$ is calculated as: $\mathrm{k}=\left(\left(\ln\right.\right.$ glucose $\mathrm{T}_{30}$-ln glucose $\left.\mathrm{T}_{60}\right) /\left(\mathrm{T}_{60}-\mathrm{T}_{30}\right)$ x $100=\%$ min. Using the estimated k-value, the glucose half-life was calculated as: $\left(T_{1 / 2}\right)=0.693 \mathrm{k} \times 100=\min$. This $T_{1 / 2}$ is defined as the time required for the glucose concentration to fall by one-half of the peak value, and it hence illustrates the clearance of the infused glucose. The insulin response following glucose infusion was illustrated by measuring the insulin peak concentration $\left(\right.$ Peak $\left._{\text {ins }}\right)$, the insulin increment (insulin peak level - basal insulin level; $\Delta \mathrm{Max}_{\text {ins }}$ ), and the area under the curve $\left(\mathrm{AUC}_{\mathrm{ins}}\right)$. The Homeostatic model assessment (HOMA) estimates steady state beta cell function and insulin sensitivity. HOMA index was calculated by the following equation: basal glucose $(\mathrm{mg} / \mathrm{dL}) \mathrm{x}$ basal insulin $(\mu \mathrm{IU} / \mathrm{mL}) / 22.5$.

Values are expressed as means \pm SEM. All of the above-mentioned parameters were tested for normality using the approximate Wilk-Shapiro test. Because all of these parameters were normally distributed, the $t$ test was carried out to estimate statistical differences between groups. Statistical analysis was done using Statistica v. 6. (StatSoft, Inc., Tulsa, OK, USA). 


\section{RESULTS}

During the spring period the average daily THI values were: $44.10 \pm 0.45$ (lactation day 30), $61.53 \pm 0.55$ (lactation day 60) and $69.52 \pm 0.64$ (lactation day 90). Similarly, the average daily THI values for the summer season were $74.48 \pm 0.34$ (lactation day 30), $76.46 \pm 0.65$ (lactation day 60), and $72.77 \pm 0.94$ (lactation day 90). Changes in average THI values during both examined periods are presented on Graph 1. During the summer season, the cows were exposed to the effects of cyclic moderate to severe heat stress.

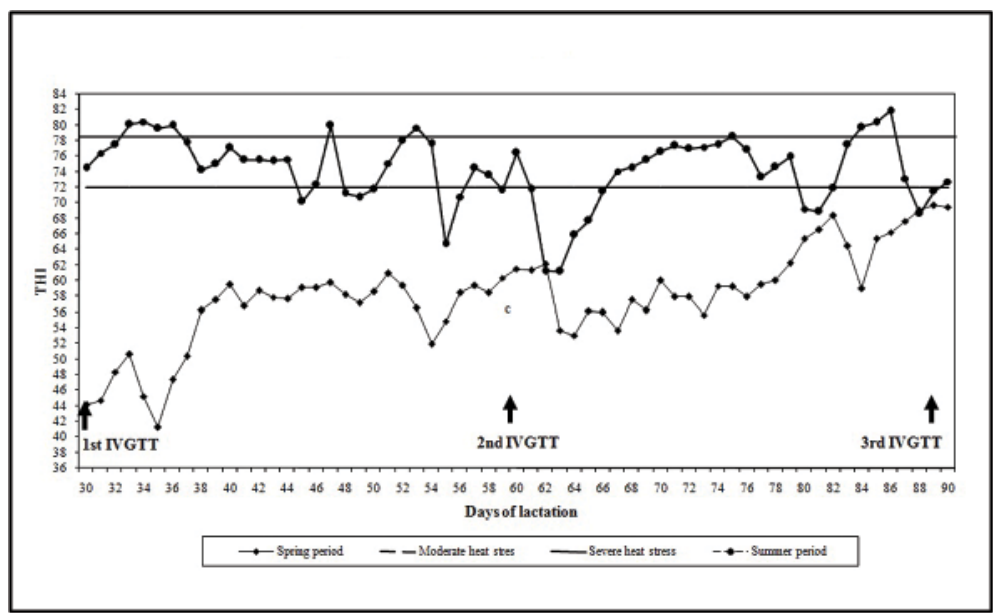

Graph 1. THI values during the spring and summer season

The average daily milk yield at the start of the spring period was $41.72 \pm 0.97 \mathrm{~L}$, after which the milk production had an increasing trend (Graph 2). On day 60 of lactation the average daily milk yield was $43.75 \pm 1.5 \mathrm{~L}$. After this period the daily milk yield did not significantly change up to the end of the trial i.e. day 90 of lactation, except at days 62, 80, 81 and 82 of lactation when it was significantly higher than on day 60 . At the start of the summer period the milk yield was 37.65 $\pm 0.89 \mathrm{~L}$ (Graph 2). After this period the average milk production per cow increased in a more marked fashion compared to the spring period. The ascending trend of the average milk production per cow is maintained with only slight variations up to day 61 of lactation when average milk yield was $43.30 \pm 1.52 \mathrm{~L}$. After day 61 of lactation, the average milk production per cow showed a marked decrease. The milk yield of the cows included in the study during the spring period was significantly higher compared to the summer from day 30 to day 40 of lactation, and from day 64 to day 90 (Graph 2). 




Graph 2. Milking yields during the summer and spring period

The basal values for blood glucose concentrations on days 30 and 60 of lactation were lower during the summer period, but this difference was not statistically significant (Table 3). On day 90 of lactation basal glycemia in dairy cows during the spring season was significantly lower $(\mathrm{p}<0.05)$ compared with the summer season. $K$ value was significantly lower, whereas $\mathrm{T}_{1 / 2}$ was significantly higher during the spring compared to the summer season on days 60 and 90 of lactation. For $\mathrm{T}_{1 / 2}$, it was also the case on day 30 of lactation. These results clearly indicate that glucose clearance during IVGTT was more pronounced during the summer (Graph 3A, 3B, 3C). In addition, glucose peaks were lower during the summer season, but significantly only on day 60 of lactation.

Levels of basal insulinemia were significantly lower in the summer season on days 30 and 60 of lactation. As expected, the lowest values for insulinemia in both examined periods were recorded on day 30 of lactation, but thereon the values increased. This increase was delayed during the summer so that on day 90 the values recorded for insulinemia was comparable between the two examined periods. Additionally, summer value of $\mathrm{AUC}_{\text {glu }}$ on day 60 of lactation was significantly lower than during the spring period. Values for $\Delta \mathrm{Max}_{\text {ins }}$ and Peak ${ }_{\text {ins }}$ were higher during the summer period compared with those of the spring season. However, these differences were significant for both parameters only on day 90 of lactation. $\mathrm{AUC}_{\text {ins }}$ was higher during the spring period on day 30 and significantly higher on day 60 of lactation. On lactation day $90, \mathrm{AUC}_{\text {ins }}$ was significantly higher in the summer period. These results clearly indicate that the insulin response significantly varied during the summer season (Graph 3D, 3E, and $3 F)$. Generally, cows exposed to heat stress during the summer season appeared to have a higher insulin response following an intravenous glucose load as compared with their spring counterparts. 


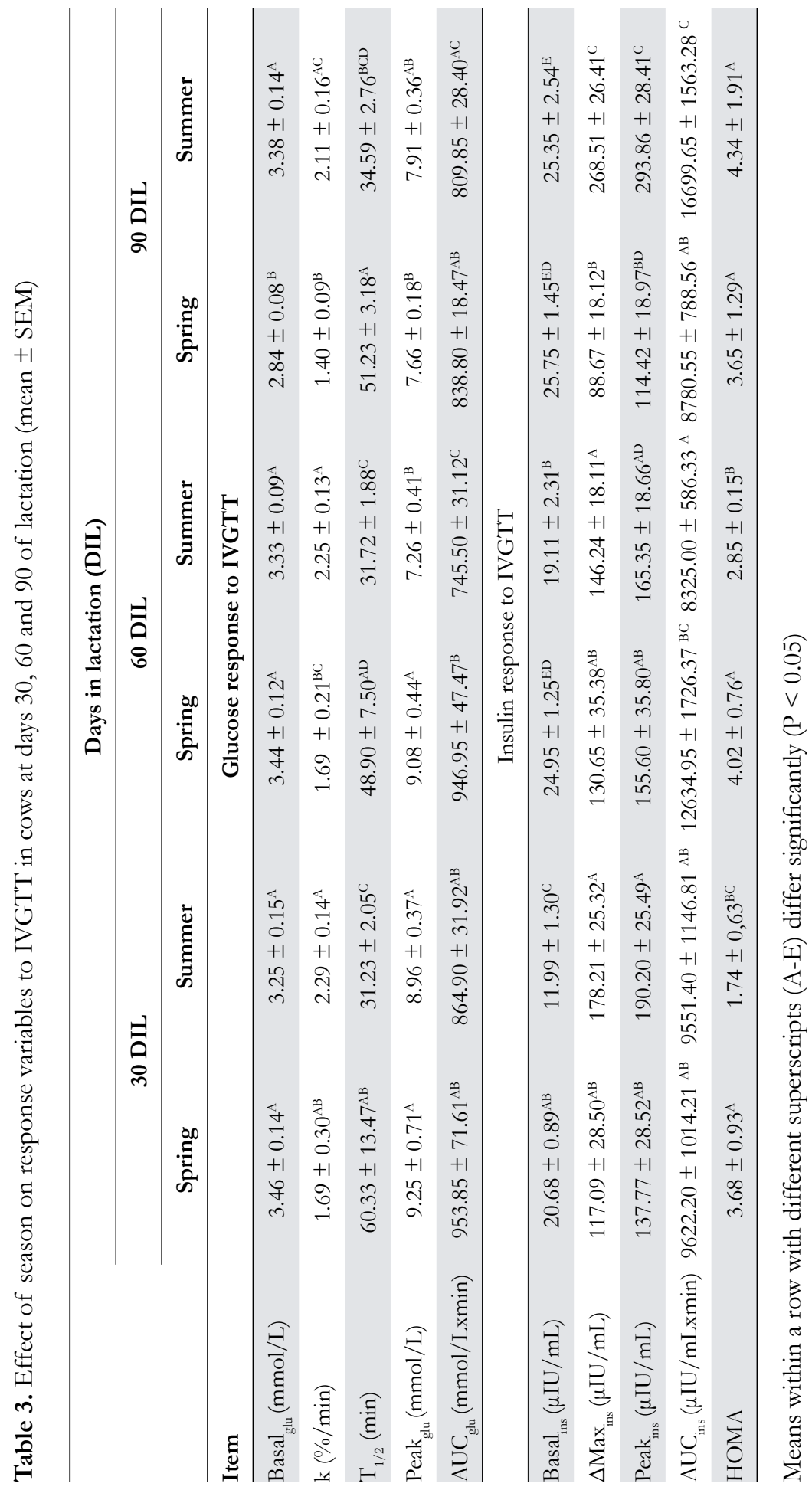



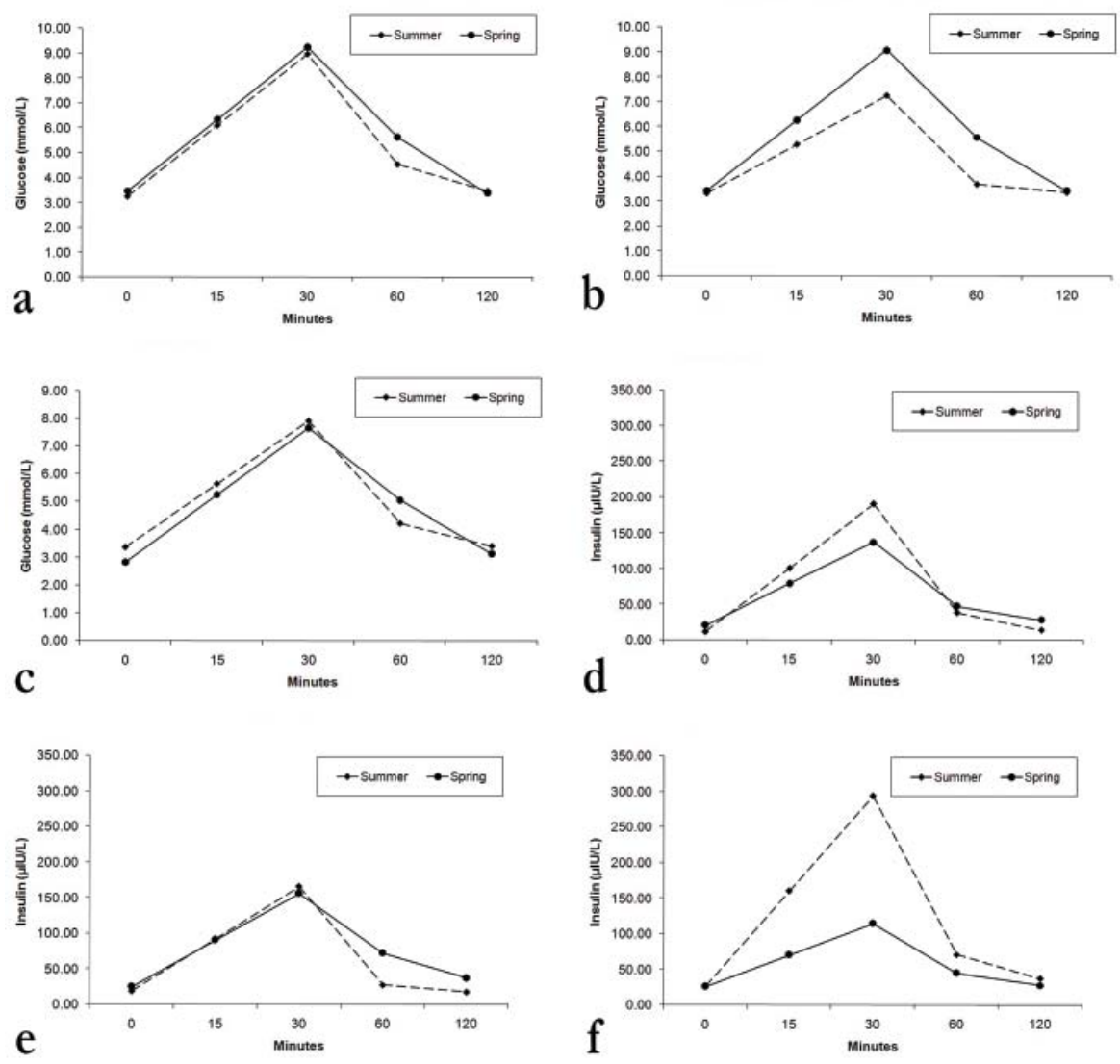

Graph 3. Effect of season on glucose (A to C) and insulin (D to F) response in cows exposed to IVGTT at days 30, 60 and 90 of lactation) (a) Glucose concentrations during IVGT'T at lactation day 30; (b) Glucose concentrations during IVGTT at day 60 in lactation; (c) Glucose concentrations during IVGT'T at day 90 in lactation; (d) Insulin concentrations during IVGT'T at day 30 in lactation; (e) Insulin concentrations during IVGTT at day 60 in lactation; (f) Insulin concentrations during IVGT'T at day 90 in lactation

\section{DISCUSSION}

As reported by Wheelock et al. (2010) [8] and Baumgard et al. (2011) [15] midlactation heat-stressed cows appear to have a preference to use glucose as an oxidative substrate. The resulting increase in insulin response shifts glucose into other peripheral tissues at the expense of the mammary gland. Whether this glucose sparing mechanism observed in midlactation cows under heat stress occurs at all lactation stages is unknown. Therefore, we examined insulin response of peripheral tissues not only 
during the midlactation period (day 90 of lactation), but also in early lactation cows (until day 60 in lactation) when homeorhetic mechanisms still exist.

During early lactation, heat-stressed cows had lower basal insulin concentrations compared with their spring counterparts (Table 3; Graph 3D and 3E). In a number of studies [8,9,16-18], but not all [19], lactating cows under heat stress condition have relatively high levels of insulin. It is well known that in early lactation in high yielding dairy cows the basal insulin concentrations are very low up to the stage when energy balance is reached [20]. Such values for insulinemia during the early stages of lactation contribute to the availability of glucose to the mammary gland [21,22]. Lower basal glucose (numerically) and particularly insulin concentrations in SU cows in this study are probably a consequence of decreased feed consumption. As discussed previously [6], on the $30^{\text {th }}$ day of lactation SU cows consumed $10 \%$ less feedstuff compared to SP cows. Additionally, in conditions of heat stress, the synthesis of volatile fatty acids in the rumen is reduced, thus minimizing their strong stimulating effect on the glucose synthesis and secretion of insulin [23]. In this regard, it has been proven that volatile fatty acids in ruminants are more potent stimulators of insulin secretion by $\mathrm{B}$ cells than it is glucose [17]. Adversely, basal glucose concentrations were lower in SP than in SU cows on the $90^{\text {th }}$ day of lactation. At the same time, basal insulinemia did not differ between seasons. Although blood glucose levels can be affected by the severity and duration of heat stress [16], higher feed intake during spring season [6] can explain, at least in part, the decreased circulating glucose concentrations and the increased milk yield in SP cows (Table 3; Graph 2).

Basal insulinemia levels increased in SU cows from day 30 to day 90 of lactation when they reached values recorded in SP cows. Unlike the summer period, in SP cows basal insulinemia measured at days 60 and 90 of lactation did not differ significantly. Given the fact that insulinemia is low up to the point energy balance is reached [25], the results of basal insulinemia in our study suggest that the energy balance of SP cows sets at the $60^{\text {th }}$ day of lactation, whereas in SU cows full recovery from negative energy balance is delayed up to the $90^{\text {th }}$ day of lactation. This assumption may be, at least in part, supported with the results related to milk production (Graph 2). Namely, after day 60 of lactation instead of maintaning milk production there is a significant decrease of milk yield in cows exposed to heat stress. Moreover, observing the milk yield of examined cows, it is obvious that day 60 of lactation is the key point in the regulation of metabolism and activity of the mammary gland. At this time dairy cows in optimal ambient conditions begin to consume enough feedstuff to meet their requirements, since the influence of catabolic hormones on metabolism decreases and the need for additional energy from endogenous sources diminishes [26]. On the contrary, cows exposed to heat stress still consume inadequate quantities of feed after day 60 of lactation, thus prolonging the period of negative energy balance $[7,19,27,28]$.

Insulin response to glucose challenge in lactating cows depends not only on production level, nutrition, body condition, stage of lactation but also from exposure of cows to heat stress $[29,30]$. As far as we know, there is no literature data related to field studies 
on insulin response to glucose challenge in cows continuously exposed to heat stress during the early lactation and midlactation periods. Recently, Tao et al., (2012) [11] presented results of insulin response to glucose challenge in dry cows exposed to heat stress and concluded that insulin response to IVGTT varies according to the phase of productive-reproductive cycle. Therefore, the results related to IVGTT in heat-stressed cows at days 30 and 60 of lactation can not be directly comparable with others.

Of particular importance to our research question is the variability in the responses to IVGTT at days 30 and 60 of lactation. Based on earlier studies [7,8,17], and because cows in the current study during the above mentioned periods in the spring season had higher circulating levels of insulin but no differences in serum glucose (versus cows in summer season), we expected that SP cows would be more insulin resistant. The HOMA index has been used to estimate differences in insulin resistance between seasons. Although this method was developed to estimate insulin sensitivity in humans and laboratory animals [31], the calculated HOMA was able to express differences between seasons and pointed at lower insulin sensitivity for SP cows. In addition, the variables calculated from the glucose and insulin profile in early lactation would further suggest insulin sensitivity effects during summer season. Cows exposed to heat stress presented enhanced glucose tolerance during IVGT'T at days 30 and 60 of lactation than cows in optimal environmental conditions. The response expressed as increased clearence rates, decreased half-life, and decreased AUC for glucose in this trial is suggested to involve increased insulin sensitivity [32]. On the other side, little can be said about changes in responsiveness, although it is noted that at day 60 of lactation peak serum glucose levels and $\mathrm{AUC}_{\text {ins }}$ were significantly lower in SU cows. Additionally, there were no differences in responses of endocrine pancreas to glucose challenge during early lactation. Therefore, it may be concluded that heat-stressed cows tend to adapt to higher environmental temperatures in this period by changing glucose metabolism pathways.

At day 90 of lactation, comparison of IVGTT results between two seasons led to an interesting findings (Table 3). Basal glucose concentrations were higher and glucose tolerance was enhanced during summer season compared to spring season. At the same time, SU cows had higher $\mathrm{AUC}_{\text {ins }}$ and $\Delta \mathrm{Max}_{\text {ins }}$, while HOMA did not differ, suggesting higher glucose-induced insulin secretion. This finding would also implicate that season differences in insulin responsiveness play a part in the glucose tolerance $\left(\mathrm{T}_{1 / 2}\right.$ and $\left.\mathrm{k}\right)$ differences. The higher insulin responses to IVGTT in cows exposed to heat stress were unexpected, since a tendency towards a lower insulin secretion is suggested in a state of enhanced glucose tolerance [29]. Moreover, a twofold increase in Peak $_{\text {ins }}$ and $\mathrm{AUC}_{\text {ins }}$ during the IVGT'T in midlactating compared to earlylactating SU cows suggests the increased pancreatic sensitivity to glucose [8]. This finding also suggests that differences in metabolic adaptations to heat stress in midlactating and earlylactating SU cows may be considerable. Altogether, the cause of enhanced sensitivity of B cells in cows exposed to continuous moderate to severe heat stress 
may be respiratory alkalosis [33,34]. A similar explanation can be drawn from the observations of Bigner et al. [35].

The results obtained in our study resemble those in studies that have investigated insulin responsiveness to glucose infusion in midlactating cows [7,8,17]. At day 90 of lactation, heat stress enhanced glucose tolerance and therefore more glucose was directed to peripheral tissues which contributed to the decrease in milk production. Due to reduced feed intake during early lactation, we expected that cows exposed to heat stress would be more metabolicaly challenged and/or that utilization of glucose by peripheral tissues would be altered in these cows. Although SU cows had significantly lower milk production at day 30 of lactation (Graph 2) we estimate that blood glucose is more directed to peripheral tissues than in cows not exposed to heat stress, as suggested by the results for $\mathrm{T}_{1 / 2}$. It is well known that in lactating cows insulinemia does not correlate with glucose utilization by the mammary gland [36], and that the overall body utilization of glucose mostly occurs through insulin-independent pathways [37]. However, no differences in milk production between groups at day 60 of lactation appeared to sufficiently explain enhanced systemic insulin sensitivity observed in SU cows in terms of glucose turnover.

\section{CONCLUSION}

In conclusion, the results from the IVGTT demonstrate season specific differences in glucose partitioning. Particularly striking was the higher glucose elimination rate in cows exposed to heat stress which was combined with lower basal insulin concentrations during early lactation as well as with higher glucose-induced insulin responses during midlactation compared to cows in optimal ambient conditions. The HOMA results supported the results from the IVGTT. Differences in glucose tolerance under heat stress conditions can be abscribed not only to the effect of milk yield, but also to the effect of stage of lactation.

\section{Acknowledgements}

The authors are very grateful to Dr Horea Šamanc, retired professor at Faculty of Veterinary Medicine University of Belgrade, Department of Farm Animal Diseases, for critical reading of this work.

Funding source: This work was supported by a project of the Ministry of Education, Science and Technological Development, Republic of Serbia (No. TR 31003).

\section{Authors' contributions}

VI was involved in field work and was involved in the creating of general idea of experiment as this study is part of his PhD work; PR obtained statistical part and was involved in calculations related to parameters related to insulin resistance; KG 
suggested model for obtained IVGTT tests and was involved in statistical analyses; JB was involved in preparing materials and animals for IVGT'T; SP was involved in analysing data related to environmental condition; PM took care of animals involved in study and carried out IVGTT tests; NS was responsible for feed analyses and calculations; $\mathrm{CD}$ obtained laboratory work; KD created an experiment and draft of the manuscript.

\section{Declaration of conflicting interests}

The author(s) declared no potential conflicts of interest with respect to the research, authorship, and/or publication of this article.

\section{REFERENCES}

1. Silanikove N: Effects of heat stress on the welfare of extensively managed domestic ruminants. Livestock Production Science 2000, 67:1-18.

2. West JW: Nutritional strategies for managing the heat stressed dairy cow. J Anim Sci 1999, 77 (Suppl. 2):21-35.

3. St-Pierre NR, Cobanov B, and Schnitkey G: Economic losses from heat stress by U.S. livestock industries. J Dairy Sci 2003, 86 (E. Suppl.):E52-77.

4. Barash H, Silanikove N, Shamay A, Ezra E: Interrelationships among ambient temperature, day length, and milk yield in dairy cows under a Mediteranian climate. J Dairy Sci 2001, 84:2314-2320.

5. West JW: Effects of heat-stress on production in dairy cattle. J Dairy Sci 2003, 86:21312144.

6. Vujanac I, Kirovski D, Šamanc H, Prodanović R, Lakić N, Adamović M, Valčić O: Milk production in high-yielding dairy cows under different environment temperatures. Large Anim Rev 2012, 18:31-36.

7. Wheelock JB, Sanders SR, Shwartz G, Hernandez LL, Baker SH, McFadden JW, Odens LJ, Burgos R, Hartman SR, Johnson RM, Jones BE, Collier RJ, Rhoads RP, VanBaale MJ, Baumgard LH: Effects of heat stress and rbST on production parameters and glucose homeostasis. J Dairy Sci 2006, 89 (Suppl. 1):290-291.

8. Wheelock JB, Rhoads RP, VanBaale MJ, Sanders SR, Baumgard LH: Effects of heat stress on energetic metabolism in lactating Holstein cows. J Dairy Sci 2010, 93:644-655.

9. Rhoads ML, Rhoads RP, VanBaale MJ, Collier RJ, Sanders SR, Weber WJ, Crooker BA, Baumgard LH: Effects of heat stress and plane of nutrition on lactating Holstein cows: I. Production, metabolism, and aspects of circulating somatotropin. J Dairy Sci 2009, 92:1986-1997.

10. Baumgard LH, Rhoads RP: The effects of hyperthermia on nutrient partitioning. Proc. $69^{\text {th }}$ Cornell Nutrition Conferenece, Cornell University, Ithaca, NY. 2007.

11. Tao S, Thompson IM, Monteiro PA, Hayen MJ, Young LJ, Dahl GE: Effect of cooling heat stressed dairy cows during the dry period on insulin response. J Dairy Sci 2012, 95:50355405. 
12. Takasu M, Kishima Y, Nishii N, Ohba Y, Maeda S, Miyazawa K, Murase T, Kitagawa $\mathrm{H}$ : Insulin and glucagon secretory patterns during propionate and arginine tolerance tests in Japanese black cattle with growth retardation. J Vet Med Sci 2007, 69:69-72.

13. Schoenberg KM, Ehrhardt RM, Overton TR: Effects of plane of nutrition and feed deprivation on insulin responses in dairy cattle during late gestation. J Dairy Sci 2012, 95:670-682.

14. Kaneko JJ: Carbohydrate metabolism and its diseases. In: Clinical Biochemistry of Domestic Animals. San Diego, CA: Academic Press; 1997, 45-81.

15. Baumgard LH, Wheelock JB, Sanders SR, Moore CE, Green HB, Waldron MR, Rhoads RP: Postabsortive carbochydrate adaptations to heat stress and monensin supplementation in lactating Holstein cows. J Dairy Sci 2011, 94:5620-5633.

16. Itoh F, Obara Y, Rose MT, Fuse H, Hashimoto H: Insulin and glucagon secretion in lactating cows during heat exposure. Journal of Animal Science 1998, 76, 2182-2189.

17. Koubková M, Knížková I, Kunc P, Härtlová H, Flusser J, Doležal O: Influence of high environmental temperatures and evaporative cooling on some physiological, hematological and biochemical parameters in high-yielding dairy cows. Czech J Anim Sci 2002, 47:309_ 318.

18. Settivari RS, Spain JN, Ellersieck MR, Byatt JC, Collier RJ, and Spiers DE: Relationship of thermal status to productivity in heat streased dairy cows given recombinant bovine somatotropin. J Dairy Sci 2007, 90:1265-1280.

19. Denbow CJ, Perera KS, Gwazdauskas FC, Akers RM, Pearson RE, and McGilliard ML: Effect of season and stage of lactation on plasma insulin and glucose following glucose injection in Holstein cattle. J Dairy Sci 1986, 69:211-216.

20. Bell AW: Regulation of organic nutrient metabolism during transition from late pregnancy to early lactation. J Anim Sci 1995, 73:2804-2819.

21. Bell AW, Bauman DE: Adaptations of glucose metabolism during pregnancy and lacatation. J Mammary Gland Biol Neoplasia 1997, 2:265-278.

22. van Knegsel ATM, Van Den Brand H, Dijkstra J, Kemp B: Effects of dietary energy source on energy balance, metabolites and reproduction variables in dairy cows in early lactation. Theriogenology 2007, 68:274-280.

23. Kamal TN, and Trenkle AH: Insulin secretory response to increasing doses of glucose and volatile fatty acids in sheep [abstract]. Nutrition Reports International 1978, 18:267.

24. Zhao FQ, Keating AF: Expression and regulation of glucose transporters in the bovine mammary gland. J Dairy Sci 2007, 90:76-86.

25. Reist M, Erdin D, von Euw D, Tschuemperlin K, Leuenberger H, Chilliard Y, Hammon H M, Morel C, Philipona C, Zbinden Y, Kuenzi N, Blum JW: Estimation of energy balance at individual and herd level using blood and milk traits in high-yielding dairy cows. J Dairy Sci 2002, 85:3314-3327.

26. Drackley JK: Biology of dairy cows during the transition period: the final frontier? J Dairy Sci 1999, 82:2259-2273.

27. Moore CE, Kay JK, Collier RJ, VanBaale MJ, Baumgard LH: Effect of conjugated linoleic acid on heat-stressed Brown Swiss and Holstein cattle. J Dairy Sci 2005, 88:1732-1740.

28. Shwartz G, Rhoads ML, VanBaale MJ, Rhoads RP, and Baumgard LH: Effects of a supplemental yeast culture on heat-stressed lactating Holstein cows. J Dairy Sci 2009, 92:935-942. 
29. Holtenius K, Agens S, Delavaud C, and Chilliard Y: Effects of Feeding intensity during the dry period. 2. Metabolic and hormonal responses. J Dairy Sci 2003, 86:883-891.

30. Prodanović R, Korićanac G, Vujanac I, Djordjević A, Pantelić M, Romić S, Stanimirović Z, Kirovski D: Obesity-driven prepartal hepatic lipid accumulation in dairy cows is associated with increased CD36 and SREBP-1 expression. Res Vet Sci 2016, 107:16-19.

31. Koricanac G, Tepavcevic S, Romic S, Milosavljevic T, Stojiljkovic M, Zakula Z: Expression and cellular distribution of glucose transporters and alpha subunits of $\mathrm{Na}+/ \mathrm{K}+$-ATPase in the heart of fructose-fed female rats: the role of estradiol. Horm Metab Res 2014, 46:109-115.

32. Kahn CR: Insulin resistance, insulin sensitivity, and insulin unresponsiveness: a necessary distinction. Metabolism 1978, 27:1893-1902.

33. Schneider PL, Beede DK, Wilcox CJ: Nycterohemeral patterns of acid-base status, mineral concentrations and digestive function of lactating cows in natural or chamber heat stress environments. J Anim Sci 1988, 66:112-125.

34. Vujanac I, Kirovski D, Šamanc H, Prodanović R, Adamović M, Ignjatović M: Glucose concentration and blood acid-basis status in high-yielding dairy cows during heat stress. Veterinarski glasnik 2011, 65:297-312.

35. Bigner DR, Goff JP, Faust MA, Burton JL, Tyler HD, Horst RL: Acidosis effects on insulin response during glucose tolerance test in Jersey cows. J Dairy Sci 1996, 79:2182-2188.

36. McGuire MA, Griinari JM, Dwyer DA, and Bauman DE: Role of insulin in the regulation of mammary synthesis of fat and protein. J Dairy Sci 1995, 78:816-824.

37. Rose MT, Obara Y, Itoh F, Hashimoto H, and Takahashi Y: Non-insulin-and insulin mediated glucose uptake in dairy cows. J Dairy Res 1997, 64:341-353.

\section{UTICAJ AMBIJENTALNE TEMPERATURE NA INSULINSKI ODGOVOR VISOKOMLEČNIH KRAVA - OGLED IZVEDEN U FARMSKIM USLOVIMA}

VUJANAC Ivan, PRODANOVIĆ Radiša, KORIĆANAC Goran, BOJKOVSKI Jovan, SIMEUNOVIĆ Predrag, PALAMAREVIĆ Milija, NEDIĆ Sreten, CELESKA Irena, KIROVSKI Danijela

Cilj ovog istraživanja bio je da se proceni glukozom indukovani insulinski odgovor kod krava izloženih različitim spoljašnjim temperaturama. Dvadeset holštajn-frizijskih krava u periodu rane laktacije su, na osnovu sezone ispitivanja, podeljene u dve jednake grupe: letnju (SU) i prolećnu (SP). Krave SP grupe nisu bile izložene toplotnom stresu, dok su krave SU grupe bile izložene umerenom do izrazitom toplotnom stresu. Dnevna proizvodnja mleka je beležena tokom ispitivanja. Počevši od 30. dana laktacije, intravenski test tolerancije glukoze (IVGTT) je izveden 3 puta u intervalima od 30 dana. Uzorci krvi su uzeti pre (bazalne vrednosti) i posle infuzije glukoze, a koncentracija glukoze i insulina je merena u svakom uzetom uzorku. HOMA indeks je izračunat. Proizvodnja mleka je, u periodima od 30. do 40. dana i 64. do 90. dana 
laktacije bila viša kod krava iz grupe SP u odnosu na krave iz grupe SU. Između grupa, bazalne glikemije se nisu razlikovale 30. i 60. dana laktacije, dok su bazalne vrednosti insulina i HOMA bili niže kod SU u odnosu na SP krave. Devedesetog dana laktacije, krave iz SU grupe imale su višu glikemiju, dok se bazalna insulinemija i HOMA indeks nisu razlikovali. IVGTT je pokazao da je tolerancija na glukozu pod uticajem toplotnog stresa, jer su krave iz SU grupe imale veći klirens glukoze. Odgovor insulina tokom IVGT'T se nije razlikovao između grupa 30. i 60. dana laktacije. Toplotni stres ima izrazit uticaj na sekreciju insulina 90. dana laktacije, što je utvrđeno na osnovu većeg porasta, pika koncentracije i AUC za insulin kod krava iz SU grupe. Uopšteno posmatrano, sezonske razlike u toleranciji na glukozu ne zavise samo od toplotnog stresa i proizvodnje mleka već i od stadijuma laktacije. 